\title{
ORIENTASI PENDIDIKAN PESANTREN SIDOGIRI
}

\author{
Oleh: Faiqoh \\ Peneliti pada Puslitbang Pendidikan Agama dan Keagamaan \\ Hp. 085795263807
}

\begin{abstract}
The purpose of this study was to determine the education orientation overview at Sidogiri Islamic Boarding School with various challenges of social changes taking place in society. This study becomes important because it attempts to reveal how Sidogiri Islamic Boarding School performs its roles according to the expectations and needs of people who require its services associated with religious services, education and other social roles. Using a case study at Sidogiri Islamic Boarding School, the data was collected through documentation study by tracing sources of relevant literature, documents or records and observation. The findings include: 1) a change in education unit form managed by Sidogiri Islamic Boarding School is essentially a change from a non-formal to formal education system, in the form of madrasah education unit. However, Sidogiri Islamic Boarding School maintains its salafi education system; 2) agents of change in the boarding school come from internal parties, particularly the founders, caregivers, directors, family assembly; 3) the boarding school always makes innovation and adaption; 4) economic independence of Sidogiri Islamic Boarding School excellently benefits the students and its caregivers and managers, which eliminate the habit or culture of begging (expecting aids / donations from others) and even can help the poor.
\end{abstract}

Keywords: Education Orientation, Sidogiri Islamic Boarding School

\begin{abstract}
Abstrak
Tujuan studi ini adalah untuk mengetahui gambaran umum tentang orientasi pendidikan di Pondok Pesantren Sidogiri dengan berbagai tantangan perubahan sosial yang terjadi di masyarakat. Penelitian ini menjadi penting karena mencoba untuk mengungkapkan bagaimana Pesantren Sidogiri melaksanakan peran-perannya sesuai dengan harapan dan kebutuhan masyarakat yang memerlukan pelayanan dari Pesantren Sidogiri yang terkait dengan pelayanan keagamaan, pendidikan dan peran sosial lainnya. Dengan menggunakan studi kasus di Pesantren Sidogiri, data diambil melalui studi dokumentasi dengan melacak sumber literatur terkait, dokumen atau arsip dan observasi. Diantara hasil temuannya adalah 1) Perubahan bentuk satuan pendidikan yang dikelola oleh pesantren Sidogiri ini pada hakekatnya merupakan perubahan dari sistem pendidikan nonformal ke sistem pendidikan formal, dalam bentuk satuan pendidikan madrasah. Namun begitu Pesantren Sidogiri masih tetap mempertahankan sistem pendidikan salafiyahnya, 2) Tokoh penggerak perubahan Pesantren ini adalah dari internal Pesantren khususnya pendiri, pengasuh, direktur, majelis keluarga. 3) Pesantren selalu melakukan inovasi dan adaptasi, 4) Kemandirian pesantren Sidogiri dalam bidang ekonomi sangat
\end{abstract}

Naskah Diterima: 10 September 2012. Revisi pertama, 9 Oktober. Revisi Kedua, 1 November 2012.

Revisi Terakhir, 25 November 2012. 
memberikan manfaat baik para santri maupun para pengasuh dan pengurusnya yang mengakibatkan tidak adanya kebiasaan atau kultur meminta-minta (mengharapkan bantuan/sumbangan dari pihak lain) bahkan dapat menyantuni masyarakat dhuafa.

Kata Kunci: Orientasi Pendidikan, Pesantren Sidogiri

\section{PENDAHULUAN}

\section{Latar Belakang}

Hakekat perubahan sistem pendidikan yang dikelola oleh setiap pesantren adalah untuk mengadopsi keinginan masyarakat sebagai pengguna layanan pendidikan pesantren. Pengadopsian sistem pendidikan di luar sistem pendidikan oleh pesantren bertujuan untuk mempertahankan eksistensi pesantren dalam fungsinya sebagai lembaga pendidikan.

Ada beberapa pesantren karena berbagai faktor cenderung mempertahankan dan melanggengkan tradisi masa lalu yang diamanatkan oleh para pendahulunya. Sistem Pendidikan yang dianutnya lebih menampakkan wajah pendidikan periode masa lalu dengan segala keunikannya dan berbeda dengan sistem pendidikan sekarang pada umumnya.

Dengan keunikannya tersebut justru memperoleh tempat tersendiri di kalangan masyarakat dan menjadi kunci utama pesantren tersebut dalam mempertahankan keberadaannya. Salah satu pesantren yang selalu berusaha untuk melanggengkan tradisi masa lalunya adalah Pesantren Sidogiri yang berada di Kabupaten Pasuruan, Jawa Timur yang tetap mempertahankan sistem pendidikan salafiyahnya atau memegang teguh prinsip salafnya dan ajaran Ahlus sunnah wal Jamaah, namun tidak mengabaikan modernitas dan era globalisasi yang tengah berkembang di lingkungan masyarakat pada umumnya. Meskipun berpegang teguh pada prinsip salafnya, tapi tidak membuat Pesantren Sidogiri melakukan berbagai pengembangan dan pembuatan inovasi-inovasi dalam penyelenggaraan sistem pendidikan dan menutup dialog dengan berbagai hal yang terkait dengan manajemen modern yang senantiasa diterapkan berdasarkan prinsip efektivitas dan efisiensi.

Pesantren Sidogiri yang terletak di Kabupaten Pasuruan Jawa Timur sejak didirikannya pada tahun 1745 sampai sekarang dengan santri yang belajar dari tahun ke tahun terjadi peningkatan yang cukup signifikan merupakan pesantren yang tetap mempertahankan salafiyahnya dengan berbagai tantangan yang dihadapi baik bentuk pendidikan formal, budaya, informasi dan kemajuan teknologi yang semakin cepat sebagai akibat tuntutan perubahan zaman. Pesantren Sidogiri dengan kesalafiyahannya tetap mengedepankan tradisi pembacaan kitab kuning sebagai bentuk upaya untuk mempertahankan tafaqquh fiddin dengan tujuan utama adalah menghadirkan kader ulama masa depan yang menurunkan tradisi para pendahulunya. Pesantren Sidogiri selalu melakukan inovasi secara terus menerus mulai kondisi awal dengan sistem tradisional (salafiyah) berupa sorogan dan wetonan, kemudian ditambahkan sistem pendidikan nonformal (klasikal) yaitu Madrasah Miftahul Ulum (MMU) baik induk maupun ranting dengan tanpa meninggalkan identitas aslinya, tanpa merubah kurikulum dan juga masih tetap melaksanakan sistem salafiyah dengan metode sorogan dan wetonan yang didukung dengan manajemen modern. Dengan keistimewaan inilah dirasa sangat penting untuk dijadikan subjek penelitian. 


\section{Permasalahan Penelitian}

Berdasarkan latar belakang tersebut, permasalahan penelitian ini untuk menjawab pertanyaan tentang bagaimana orientasi pendidikan pesantren Sidogiri.

\section{Tujuan Penelitian}

Penelitian ini bertujuan untuk mengetahui gambaran umum tentang orientasi pendidikan di Pondok Pesantren Sidogiri dengan berbagai tantangan perubahan sosial yang terjadi di masyarakat. Penelitian ini menjadi penting karena mencoba untuk mengungkapkan bagaimana Pesantren Sidogiri melaksanakan peran-perannya sesuai dengan harapan dan kebutuhan masyarakat yang memerlukan pelayanan dari Pesantren Sidogiri yang terkait dengan pelayanan keagamaan, pendidikan dan peran sosial lainnya.

\section{Metode Penelitian}

Tulisan ini diangkat dari hasil penelitian penulis di Pesantren Sidogiri pada bulan September 2012. Data diambil melalui studi dokumentasi dengan melacak sumber literatur terkait, dokumen atau arsip sejarah, hasil penelitian, dan jurnal tentang Pesantren Sidogiri; wawancara mendalam (indepth interview) dengan sejumlah narasumber (key informan), pelaku/aktor, mereka yang terlibat dengan berbagai peran yang dimiliki; dan observasi di kantor pusat pesantren dan lingkungan Pesantren Sidogiri untuk mengangkat realita secara lebih utuh dengan tetap menggunakan pendekatan empirik, artinya peneliti berupaya menangkap dan memahami fenomena yang ada, sebagaimana komunitas pesantren memaknai realitas tersebut.

\section{Kerangka Konsep}

Orientasi pendidikan mengandung makna bagaimana pendidikan difahami, dimaknai, dan harapan apa yang diperoleh dengan pendidikan yang dibangun. Peran pendidikan pada dasarnya mencakup 2 (dua) peran, continuity (preservation) dan perubahan (social change). Peran continuity (preservation) antara lain peran sosialisasi, menjaga identitas kultural (cultural identity), menjaga dan melanggengkan tradisi dan budaya masyarakat dimana pendidikan berlangsung. Sementara peran perubahan bagaimana menjadikan pendidikan sebagai wahana transfer pengetahuan (knowledge), sains dan teknologi, nilai-nilai modernitas, dan berbagai ketrampilan berbasis teknologi.

Berkaitan dengan teori perubahan, para ilmuwan sosiolog berpendapat bahwa kecenderungan kepada perubahan sosial adalah gejala yang wajar, timbul dari pergaulan hidup manusia. Menurut Gazalba (1983), terjadinya perubahan sosial ialah karena timbulnya perubahan pada unsurunsur yang mempertahankan keseimbangan masyarakat, misalnya perubahan pada unsur geografi, biologi, ekonomi atau kebudayaan.

Seokanto berpendapat bahwa perubahan sosial terjadi karena kondisi-kondisi sosial primer, misalnya kondisi ekonorni, teknologi, geografi atau biologi. Kondisikondisi inilah yang menyebabkan terjadinya perubahan pada aspek-aspek kehidupan sosial lainnya. Pendapat selanjutnya ialah, semua kondisi tersebut sama pentingnya, baik salah satu ataupun kesemuanya memungkinkan terjadinya perubahan sosial (Seokanto S, 1974).

Suatu sistem sosio budaya semenjak wujudnya ada, tidak henti-hentinya bekerja dan bertindak. Dalam menghadapi lingkungan tertentu sistem itu menimbulkan perubahan, di samping dirinya sendiri juga ikut mengalami perubahan. Karena teIah mengalami perubahan, maka dalam menghadapi lingkungan yang sama dengan yang sebelumnya, ia memberikan reaksi yang berbeda, dari pada reaksinya yang pertama. Jadi lingkungan tetap Sama, tapi sistem 
itu dan reaksinya berubah, demikianlah selanjutnya, reaksinya yang ketiga terhadap lingkungan yang sama mengalami pula perubahan. Perubahan tidak hanya pada sistem dan reaksinya, tapi juga pada lingkungan itu sendiri (Gazalba, 1983).

\section{HASIL DAN PEMBAHASAN}

\section{Program Pendidikan}

Pesantren Sidogiri (PS) merupakan lembaga pendidikan keagamaan yang memegang teguh prinsip salaf dan ajaran Ahlussunnah wal Jamaah, memiliki tanggung jawab besar dalam upaya melestarikan dan mengabadikan ajaran-ajaran Islam Ahlussunnah terutama di Indonesia. Dalam menjalankan misi pendidikan keagamaan ini, Pesantren Sidogiri menganut prinsipprinsip ulama salaf dimana pengajaran kitab-kitab klasik tetap dijadikan sebagai inti pendidikan yang ditunjang pengelolaan Pesantren dengan teknologi modern disesuaikan dengan tuntutan perkembangan zaman. Saat ini sistem pendidikan yang berkembang di Pesantren Sidogiri adalah salafiyah murni dan pendidikan formal.

Sejak awal berdirinya pada tahun $1745 \mathrm{M}$ atau $1158 \mathrm{H}$ sampai pada masa kepengasuhan KH. Abd Djalil, tepatnya pada 14 Safar 1357 atau 15 April 1938 kegiatan pesantren hanya berbentuk pengajian bandongan/wetonan atau layanan kolektif (collective learning process) dan sorogan atau layanan individual (individual learning process) yakni mengaji kepada Pengasuh yang merupakan tradisi pendidikan asli (indigenous) dari berbagai pesantren di Jawa dan Madura bahkan di Indonesia yang dilaksanakan di Dalem Kiai atau surau Daerah H.

Pendidikan Salafiyah murni yang dilaksanakan Pesantren Sidogiri menggunakan metode sorogan dan bandongan/wetonan yang dilaksanakan setiap selesai sholat lima waktu, dan musyawarah. Metode pengajaran ini juga dipergunakan oleh Pesantren di
Jawa dan Madura pada umumnya yang merupakan ciri khas pesantren salafiyah.

Masa kepengasuhan KH. Abd Djalil, sesuai dengan perkembangan dan tuntutan zaman, pesantren mengubah sistem pendidikannya dengan penerapan sistem pengajian ma'hadiyah dan sistem pendidikan madrasiyah yaitu dengan mendirikan madrasah yang diberi nama Madrasah Miftahul Ulum (MMU) sebagai pembekalan bagi mereka yang belum mampu mengikuti pengajian tersebut. Seiring bertambahnya murid secara bertahap MMU terus melakukan pengembangan dari hari ke hari terutama yang berkenaan dengan sistem. Hingga saat ini, Madrasah Miftahul Ulum memiliki empat jenjang tingkatan: Istidadiyah, Ibtidaiyah, Tsanawiyah, dan Aliyah.

Pendirian MMU ini pun tidak terlepas dari tujuan pendirin pesantren sebelumnya yaitu pesantren yang berpegang teguh pada Islam Ahlussunnah wal Jama'ah, memiliki tanggung jawab besar dalam upaya melestarikan dan mengabadikan ajaran-ajaran Islam Ahlussunnah wal Jama'ah terutama di Indonesia dengan memfokuskan pesantren yang menjalankan tugas fungsinya sebagai satuan pendidikan yang mempersiapkan peserta didik menjadi anggota masyarakat yang memahami dan mengamalkan nilainilai ajaran agamanya (Tafaqquh Fiddin). Performance insan pesantren ditandai dengan kemantapan akidah, kedalaman spiritual, keluhuran akhlak, berpengetahuan luas, disiplin tinggi, haus dan cinta ilmu pengetahuan, serta perilaku positif sebagai manifestasi da'wah.

Sistem MMU telah berjalan dengan baik. Sistem pendidikan pesantren yang dilaksanakan dengan dua sistem yaitu sistem ma'hadiyah dan sistem madrasiyah (klasikal) untuk jenjang Ibtidaiyah telah berjalan kurang lebih selama 19 tahun. Kemudian didirikanlah jenjang berikutnya, yang merupakan jenjang lanjutan. Berdiri pada bulan Dzulhijjah $1376 \mathrm{H}$, bertepatan dengan bulan Juli 1957 M. Jenjang ini diselesaikan 
selama 3 tahun dengan waktu belajar dari jam 12.20 sampai 17.00 karena ruang kelasnya bergantian dengan MMU Ibtidaiyah. Merupakan upaya pendalamam akidah dan perkembangan kreativitas murid yang berfokus pada Annajah. Kegiatan utama penunjangnya adalah kursus akidah, fiqh kemasyarakatan, dan tasawuf. Annajah juga menerbitkan majalah dinding dan sejak tahun 1961 lulusan MMU Tsanawiyah berkewajiban melaksanakan tugas sebagai guru tugas dan dai di beberapa daerah di Indonesia selama satu tahun untuk mendapat ijazah kelulusan. Menurut KH. Mahmud Ali Zain mereka tidak boleh magang di tempat asalnya sendiri dalam rangka membuat kematangan dirinya terhadap penguasaan materi secara teori dan praktek.

Pencipta MMU Tsanwiyah ini adalah KH Chalil Nawawi pada tahun 1957 M. Periode MMU Tsanawiyah ini terjadi pada tahun 1957 - 1982 M (25 tahun). Tujuan dari MMU Tsanawiyah ini sebagai kelanjutan dari MMU Ibtidaiyah adalah santri memiliki ilmu pengetahuan agama untuk dirinya sendiri dan kepentingan masyarakat minimal mereka sudah mampu menjadi Imam Shalat Maktubah (lima waktu) di daerahnya.

Jenjang MMU Aliyah merupakan jenjang lanjutan MMU Tsanawaiyah. Berdiri pada bulan 3 Muharram $1403 \mathrm{H}$ atau 21 Oktober 1982 M. Jenjang ini diselesaikan selama 3 tahun. Ada 3 kiai yang berperan dalam pendiriannya yaitu (1) KH. Sirojulmillah Waddin bin Nawawie, (2) KH. Hasani bin Nawawi, (3) KH. Abdul Alim bin Abd. Jalil. Tujuannnya adalah agar selelsai Aliyah menjadi tenaga pengajar pada tingkat di bawahnya, akhlaqnya bertambah baik dan menjadi alim fiqih. Dakam tahun 2005 M, MMU Aliyah menerapkan sistem kejuruan untuk murid-murid yang sudah berada pada semester III dan IV. Jurusan yang disediakan adalah : Jurusan tarbiyah, dakwah, dan Muamalah, dan pada tahun 2006 MMU Aliyah Pesantren Sidogiri mendapatkan penghargaan dari Departemen
Agama yaitu akreditasi MMU Aliyah (formal) dan sebagai konsekuensi logis maka lulusan MMU Aliyah berhak masuk sekolah ke tingkat tinggi seperti UIN, dan bahkan lulusan terbaik mendapatkan beasiswa untuk melanjutkan ke salah satu perguruan tinggi di Yaman, menerima beasiswa di STEI Tazkia Institut Bogor dan bahka pada tahun 2009 (1430 H) Pesantren telah menerima faksimili dari Duta Besar Mesir untuk Indonesia yang isinya adalah pengakuan/ penyetaraan (Mua'dallah) Ijazah MMU Aliyah oleh Universitas al-Azhar, Kairo Mesir.

Tujuan didirikannya MMU Aliyah Tarbiyatul Muallimin adalah menjalankan fungsinya sebagai satuan pendidikan yang mempersiapkan peserta didik menjadi anggota masyarakat yang memahami dan mengamalkan nilai-nilai ajaran agamanya (tafaquh fiddin) dimana performance insan pesantren ditandai dengan kemantapan akidah, kedalamam spiritual, keluhuran akhlak, berpengetahuan luas, disiplin tinggi, haus dan cinta ilmu pengetahuan, serta perilaku positif sebagai manifestasi dawuh, Khoirunnas anfa'uhum linnas. Selain itu MMU Aliyah bertujuan agar santri memiliki ilmu pengetahuan agama sebagaimana yang diperoleh pada jenjang sebelumnya, dan bertambah dapat menjadi Khatib dan Imam Jum'atan di berbagai masjid dan mampu berdakwah di mana mereka berada.

Sekalipun ijazah MMU Aliyah berla$\mathrm{ku}$ formal, konsentrasi yang ditekuni para murid MMU Aliyah tetap seperti sediakala, yakni mempelajari ajaran-ajaran dan nilainiali Islam yang luhur, dari sumber-sumber yang masih jernih, yakni dari ajaran-ajaran para ulama salafus shaleh. Kajian akidah, fiqh dan akhlak menjadi pokok pelajaran yang paling asasi, karena ini merupakan cerminan dari upaya untuk memahamai dan memperdalam akidah Islam ahlusunnah wal Jamaah, mengetahui dan mengejawantahkan ajaran fiqh Islam di tengah-te- 
ngah masyarakat, sekaligus menghiasinya dengan akhlak al-karimah.

Selain Madrasah Miftahul Ulum Pusat yang telah berdiri dengan berbagai jenjang yang ada, maka sejak tahun 1961, KH Sa'doellah Nawawie menggagas berdirinya madrasah ranting dengan tujuan untuk meningkatkan Madrasah Diniyah yang ada di Pesantren Sidogiri. Madrasah yang pertama kali dibangun menjadi ranting adalah madrasah yang terletak di Desa Jeruk. Tahun 1982 jumlah madrasah ranting menjadi 7 madrasah. Karena kian lama madrasah ranting tersebut kian banyak, maka diadakanlah penomoran terhadap madrasah ranting. Madrasah ranting yang bernomor satu adalah madrasah di Desa Lebaksari.

Saat ini ada dua klasifiaksi MMU Ranting. Pertama MMU Ranting tipe A, yaitu: madrasah ranting yang berada di Kabupetan Pasuruan, dan kedua adalah madrasah ranting tipe B, yaitu: madrasah yang terletak di luar Kabupaten Pasuruan. Secara global ada beberapa target keuntungan yang diupayakan bagi MMU Ranting. Demi terwujudnya target tersebut, MMU Induk/ Pusat mengupayakan dengan beberapa langkah yaitu semisal melalui pelatihan keguruan dan manajemen, memfasilitasi terbentuknya koperasi madrasah, kontrol MMU Induk ke MMU Ranting secara rutin dan terjadwal, mengadakan Musabaqoh antar Madrasah ranting (MUAMMAR) dan mengupayakan adanya sarana prasarana semisal komputer. Rapat kordinasi dengan MMU Ranting diadakan tiga kali setiap menjelang IMDA atau IMNI yang bertujuan untuk mensosialisasikan program atau kegiatan baru terkait MMU Ranting, sekaligus menampung aspirasi dari pihak MMU Ranting.

Jumlah madrasah ranting kian tahun kian bertambah. Pada tahun ini MMU Ranting Ibtidaiyah bertambah 3 madrasah : Ranting A-68 Sumber Banteng Kejayan Pasuruan, MMU ranting B-34 Raas Timur Gelbung Galis Bangkalan, dan MMU Ranting
B-35 Batu Ampar Gunung Sereng Kwanyar. Total MMU Ranting Ibdtidaiyah adalah 111 (tipe A : 71, tipe B : 40), sedangkan MMU Ranting Tsanawiyah adalah 31 (tipe A: 19, tipe B; 12). Secara rinci jumlah murid pada MMU Ranting adalah sebagi berikut :

$\begin{array}{lll}\text { 1. Ibtidaiyah A } & : 71 \text { Madrasah } & : 5359 \text { murid } \\ \text { 2. Ibtidaiyah B } & : 40 \text { Madrasah } & : 7398 \text { murid } \\ \text { 3. Tsanawiyah A } & : 17 \text { Madrasah } & : 326 \text { murid } \\ \text { 4. Tsanawiyah B } & : 14 \text { Madrasah } & : 524 \text { murid }\end{array}$

\section{Penguatan Nilai-nilai Salafiyah dalam Pendidikan Pesantren Sidogiri}

Pesantren Sidogiri merupakan pesantren bertipologi salafiyah. Walaupun pesantren Sidogiri sudah membuka sistem klasikal namun berbagai jenis kegiatan kesalafiyahan di Pesantren masih tetap eksis dan berjalan. Adapun jenis kegiatan tersebut sebagaimana berikut:

Tahajud, Witir, dan Subuh Berjamaah. Kegiatan ini diikuti seluruh santri dan dimulai pukul 03.30 WIS (dini hari). Setelah mandi/berwudu, seluruh santri melaksanakan salat Tahajud dan Witir. Untuk murid kelas VI Ibtidaiyah, Tsanawiyah, dan anggota Kuliah Syariah yang tidak memiliki tugas di Daerahnya, kegiatan ini bertempat di masjid. Setelah itu, dilanjutkan dengan membaca Asma'ul Husna bersama. Sedangkan untuk kelas I sampai V Ibtidaiyah dan murid Istidadiyah, kegiatan ini bertempat di daerah masing-masing. Dilanjutkan dengan membaca wirid-wirid mu'tabarah.

Takrar Nazham. Kegiatan ini khusus untuk murid kelas I sampai V Ibtidaiyah dan murid Istidadiyah, bertempat di daerah masing-masing. Kegiatan Pagi. Kegiatan Pagi di daerah dilaksanakan setelah salat Subuh sampai dengan pukul 06.00 istiwak. Kegiatan ini dilaksanakan di dalam kamar, dipandu oleh Kepala Kamar. Antara lain diisi dengan pembinaan baca kitab, me- 
lengkapi makna kitab pelajaran, pengajian kitab, pendidikan al-Qur'an.

Shalat Dhuha Berjemaah. Kegiatan Sholat Dhuha Berjamaah diperuntukkan bagi murid kelas I sampai $\mathrm{V}$ jenjang Ibtidaiyah dan Istidadiyah yang dilaksanakan pada pukul 06.30 s.d. 06.45 pagi, dan bertempat di daerah. Sedangkan pada hari Jumat, pelaksanaan salat Dhuha berjemaah diganti dengan musyawarah di daerah.

Pengajian Kitab Kuning. Pengajian kitab kuning ada yang diasuh langsung oleh Kiai/Pengasuh, dan ada yang dibacakan guru-guru yang ditunjuk Pengurus bagian pengajian kitab Ma'hadiyah atas persetujuan Ketua III PS. Pengajian kitab kuning oleh Pengasuh adalah kegiatan paling inti di Pesantren Sidogiri. Bertempat di Surau H dan harus diikuti oleh: (1) anggota Kuliah Syariah selain guru, (2) guru yang sedang tidak bertugas, dan (3) murid Aliyah. Sedangkan santri tingkat Tsanawiyah, Ibtidaiyah, dan Istidadiyah sangat dianjurkan mengikuti pengajian yang diasuh oleh Pengasuh, selama tidak bertentangan dengan kegiatan madrasah yang lebih wajib. Materi pengajian kitab kuning oleh Pengasuh di antaranya adalah kitab Ihya' Ulûmiddîn, Shahîh al-Bukhâri, Fathul-Wahhâb, I'ânatuth-Thâlibîn (pagi); Tafsîr Jalâlain (sore); dan Jam'ul-Jawâmi' (malam). Sementara itu, mengikuti pengajian kitab yang dibacakan guru-guru juga wajib bagi semua santri PS. Tempatnya di ruang-ruang MMU atau daerah, ba'da Maghrib setelah pendidikan baca. Materi pengajian tersebut adalah kitab-kitab kecil dalam bidang Fikih, Akhlak, Tasawuf, Nahwu, dan lainnya. Metode yang digunakan dalam pengajian kitab ini ada yang memakai sorogan, bandongan, juga ada yang berupa pendidikan cara baca kitab.

Musyawarah Ma'hadiyah. Kegiatan musyawarah untuk anggota Kuliah Syariah diselenggarakan setiap malam, pukul 09.00 s.d. 10.00 WIS, bertempat di ruang-ruang MMU. Khusus malam Selasa, musyawarah dilaksanakan pukul 08.00 s.d. 10.00. Se- dangkan untuk tingkat Tsanawiyah, sesuai ketentuan Daerah dan kelasnya, musyawarah dilaksanakan Selasa pagi pukul 05.30 s.d. 07.00, bertempat di ruang MMU. Dan bagi santri kelas V \& VI Ibtidaiyah serta V, VI, dan VII Istidadiyah dilaksanakan Jumat pagi pukul 06.00 s.d. 07.00, bertempat di daerah. Selain itu, kegiatan musyawarah ada yang diistilahkan dengan Musyawarah Gabungan antar Daerah, bagi murid kelas III Tsanawiyah. Musyawarah ini membahas masalah waqi'iyah (banyak terjadi di masyarakat) dan dilaksanakan malam Jumat pukul 09.30 s.d. 11.00 secara bergantian di tiap-tiap daerah.

Salat zuhur dan Asar Berjamaah. Kegiatan ini untuk murid Ibtidaiyah dan Istidadiyah dimulai pukul 12.20 sampai 12.45 . yang bertempat di daerah untuk kelas I sampai $\mathrm{V}$, dan bertempat di masjid untuk kelas VI. Salat Magrib Berjemaah. Kegiatan ini bertempat di masjid untuk kelas VI Ibtidaiyah, murid Tsanawiyah, dan semua anggota Kuliah Syariah yang tidak bertugas di daerahnya. Sedangkan kelas I sampai V Ibtidaiyah dan murid Istidadiyah bertempat di daerah.

Pendidikan Baca al-Qur'an. Pendidikan Baca al-Qur'an (Ta'lim al-Qur'an) harus diikuti oleh seluruh santri selain kelas VI Ibtidaiyah \& III Tsanawiyah, setelah salat Magrib berjemaah. Kegiatan ini diselenggarakan setiap malam, selain malam Selasa dan malam Jumat. Kegiatan mengaji alQur'an bertempat di daerah untuk anggota Kuliah Syariah dengan cara tadarus. Bertempat di kamar-kamar daerah untuk kelas I sampai V Ibtidaiyah dan murid Istidadiyah. Sedangkan untuk kelas I \& II Tsanawiyah bertempat di ruang-ruang MMU. Kegiatan ini dipandu oleh seorang muallim (guru mengaji) yang ditunjuk Pengurus bagian taklim al-Qur'an.

Baca Istighfar dan Salawat Ba'da Magrib. Kegiatan ini dilaksanakan setiap malam untuk kelas VI Ibtidaiyah dan III Tsanawiyah, bertempat di masjid setelah pelaksanaan shalat Magrib berjamaah. Khusus malam 
Selasa, ditambah dengan kelas I dan II MTs. Kegiatan ini dilaksanakan setiap malam Selasa dan juga dilaksanakan di Daerah, yang harus diikuti oleh kelas I sampai V Ibtidaiyah dan murid Istidadiyah. Pada malam Selasa, setelah kegiatan ini diadakan tausiyah (ceramah pencerahan).

Membaca Burdah. Kegiatan ini dilakukan bergantian setiap malam, sesuai dengan urutan daerah yang ditetapkan Pengurus. Pembacaan Burdah ini dilakukan dengan dua cara, yitu Burdah Keliling dan Burdah di Daerah. Burdah Keliling dibaca sambil mengelilingi komplek pesantren oleh semua santri tingkat Tsanawiyah, sedangkan Burdah di daerah dibaca bersama di Daerah. Kegiatan ini dilaksanakan pada pukul 11.30 s.d. 12.00 malam, kecuali bagi daerah-daerah tertentu.

Gerak Batin (istighatsah). Kegiatan ini bertempat di masjid, diikuti oleh seluruh santri sesuai urutan daerahnya. Waktunya sama dengan pembacaan Burdah, yaitu pukul 11.30 s.d. 12.00 malam. Gerak batin ini diisi dengan membaca Munjiyat yang diakhiri dengan membaca Hizbul-Futuh.

Membaca Shalawat dan Madah Nabi. Pembacaan Salawat dan Madah Nabi dilaksanakan setiap malam Jumat, pukul 07.30 s.d. 08.30 (ba'da Isya'). Kegiatan ini bertempat di masjid untuk anggota Kuliah Syariah, dan bertempat di daerah untuk tingkat Istidadiyah, Ibtidaiyah, dan Tsanawiyah. Sedangkan salawat dan madah yang dibaca adalah, Maulid ad-Diba'iy, Maulid alBarzanji, Syaraful Anam, dan Simthud-Durar. Dalam satu bulan, empat macam salawat ini dibaca secara bergantian tiap malam Jumat.

Baca Ratibul-Haddad dan Surat al-Kahfi. Pembacaan wirid ini hanya dilaksanakan oleh santri kelas I sampai V murid Ibtidaiyah dan Istidadiyah, dengan dipandu oleh Ubudiyah daerah. Kegiatan ini dilaksanakan hari Jumat setelah shalat Subuh berjamaah, bertempat di daerah. Kegiatan ini dilanjutkan dengan pembacaan Surat al-Kahfi yang diikuti oleh semua warga daerah. Pelaksanaannya setelah kegiatan salat Subuh berjamaah di masjid dan surau sudah selesai.

Baca Surat-Surat Munjiyat. Waktu pelaksanaan kegiatan ini adalah Jumat sore, pukul 17.00 s.d. 17.30 WIS, bertempat di Daerah. Berkaitan dengan jadwal mengaji ke pengasuh dilaksanakan tiap pukul 08.00 WIS s.d. 11.00 WIS selain Selasa dan Jumat. Kegiatan ini wajib diikuti oleh anggota Kuliah Syariah dan dianjurkan untuk murid Tsanawiyah. Kitab-kitab yang diajikan meliputi, Ihyā' 'Ulūmiddīn, Fathul-Wahhāb, Shahīh Bukhāri, Hāsyiyah al-Bannāni, dan lain-lain. Pada malam Rabu, melalui forum kajian Adab, LPSI menyelenggarakan diskusi ilmiah bertajuk "Mu'jizat al-Qur'an dalam Perspektif Ulama Nahwu" dengan mengundang Ust. Mahmudi asy-Syanqithi, Malang. Kegiatan ini rutin digelar tiap bulan oleh forum-forum kajian secara bergilir. Sedangkan malam Selasa, Kuliah Syariah mendatangkan KHA. Mujib Imron, MA dalam acara Tausiyah, yaitu acara penyegaran yang dimaksudkan untuk memberikan semangat baru terhadap anggota Kuliah Syariah dalam menjalani kegiatan terutama kegiatan mengaji ke Pengasuh. Dan malam Jumat, Kuliah Syariah menggelar kursus manasik haji dan diikuti oleh 125 peserta. Kegiatan kursus ini rutin dilaksanakan setidaknya tiga kali dalam setahun. Selain manasik haji, Kuliah Syariah juga menggelar kursus haid, faraid, dan ilmu falak.

\section{Pengadopsian Unsur-unsur Modernitas: Pemanfaatan Media Komunikasi dan Pe- nguatan Ekonomi}

Pesantren salafiyah sesuai dengan tuntutan zaman perlu melakukan suatu pola dakwah kontemporer melalui budaya global dan budaya modern. Pola dakwah kontemporer adalah suatu pola dakwah yang berbeda dengan dakwah konvensional, salah satunyanya adalah penggunaan media dakwah melalui televisi, CD, Internet dan bulletin. Di Pesantren Sidogiri, para santri 
senior diberi fasilitas untuk mengembangkan bakat tulis-menulis. Beberapa lembaga intern di pesantren Sidogiri secara terjadwal menerbitkan media, mulai majalah dinding, buletin, majalah, hingga media online.

Perubahan pola diawali pada kepemimpinan KH Abd Alim Abd Djalil, dengan terbitnya Majalah IJTIHAD yang dikelola oleh murid-murid MMU Aliyah pada tahun $1414 \mathrm{H} / 1994$ M., yang kemudian disusul dengan kelahiran beberapa media lainnya. Periode kepengurusan 1428-1430 $\mathrm{H}$, pesantren Sidogiri mendirikan Badan Pers Pesantren (BPP). Ada 3(tiga) standard umum media Sidogiri: 1) tidak bertentangan dengan paham Ahlussunnah wal Jamaah, baik secara akidah, syariah, maupun akhlak, 2) tidak bertentangan dengan tradisi luhur pesantren yang diteladankan oleh para Masyayikh Sidogiri; dan 3) tidak rentan menimbulkan keresahan di masyarakat.

Saat ini, 14 media yang secara fungsional berada di bawah naungan BPP, terdiri atas 4 majalah, 3 buletin, 6 majalah dinding, dan 1 media online (website). Oplah empat majalah dan tiga buletin terbitan pesantren terus mengalami peningkatan. Banyaknya media yang terbit di pesantren tentunya didukung banyaknya santri yang berkompeten dalam tulis-menulis. Para penulis itu rata-rata mulai belajar menulis di majalah dinding. Ada 6 majalah dinding yang terbit dan dikumpulkan di satu tempat.

Bertepatan dengan hari Jadi Pesantren Sidogiri ke-268, pada bulan Syaban 1426 H., Majelis Keluarga Pesantren Sidogiri menerbitkan Buletin SIDOGIRI (BS) yang mengangkat tema-tema aktual dari sudut pandang salaf. Ditambah kajian-kajian keislaman dari berbagai disiplin ilmu. Kajian-kajian inilah yang diharapkan dapat mengimbangi wacana-wacana keislaman di media mainstream yang berseberangan dengan paham Ahlusunah wal Jamaah. Dengan memanfaatkan kekuatan jaringan yang dimiliki alumni, wali santri, dan simpatisan pesantren Sidogiri, oplah rata-rata
Buletin SIDOGIRI saat ini mencapai 9.000 s.d 10.000 eksemplar setiap edisi, dengan pasar distribusi meliputi Pulau Jawa, Bali, Sumatera, Kalimantan, dan Sulawesi.

Pada sisi lain berkaitan dengan media komunikasi, para santri yang masih belajar di pesantren Sidogiri tidak diperbolehkan menerima berita dari $t v$, koran dan radio, karena pengurus Pesantren Sidogiri khawatir para santri menerima paham yang bertentangan dengan paham Ahlussunnah wal Jamaah, baik secara akidah, syariah, maupun akhlak. Begitupula penggunaan internet dan hp juga dibatasi karena pengurus pesantren sulit memfilter gambargambar porno yang khawatir dilihat para santri.

Dari paparan di atas terlihat bahwa Pesantren Sidogiri sebagai pesantren salafiyah dalam menyikapi perkembangan teknologi informasi bersikap menerima tapi tetap memfilter baik dan buruknya penggunaan IT.

Fokus Pesantren Sidogiri adalah ibadah, pendidikan sikap dan hati, serta pendalaman terhadap ilmu-ilmu agama. Materi kurikulum yang diajarkan adalah materi keagamaan yang bersumber dari kitab-kitab salaf (kutubut-turāts). Pencerahan dilakukan secara menyeluruh, meliputi semua ranah kognitif, afektif dan psikomotorik, dengan tetap menonjolkan pendidikan sikap dan hati. Keteguhan terhadap prinsip salaf tidak kemudian membuat Pesantren Sidogiri menutup dialog dengan perkembangan waktu. Hal-hal yang terkait dengan manajemen dan tata kelola senantiasa diterapkan berdasarkan standar efektivitas dan efisiensi yang tentu saja berjalan sesuai dengan arus perkembangan di ranah tersebut. Inti pendidikan di Pesantren Sidogiri tidak berubah dari garis yang telah dibuat oleh para pendirinya.

Bagi Pesantren Sidogiri, pesantren agaknya bukan hanya sekedar sebagai lembaga pendidikan keagamaan untuk mencetak generasi berperilaku islami, tetapi se- 
kaligus mampu membuktikan diri sebagai lembaga perekonomian guna mensejahterakan santri serta masyarakat luas. Pesantren Sidogiri juga melatih para santrinya untuk menangani bidang perekonomian. Untuk itu sejak tahun 1961, KH. A. Sa'doellah Nawawie merintis berdirinya koperasi yang kemudian bernama Kopontren Sidogiri sebagai wadah untuk belajar kemandirian, wirausaha (enterpreneurship) dan pengabdian bagi para santri. Kegiatan usaha pertamanya adalah membuka kedai dan warung kelontong di dalam lingkungan pesantren yang menyediakan kebutuhan sehari-hari para santri. Keberadaan Kopontren Sidogiri itulah yang kemudian menjadi cikal bakal kebangkitan ekonomi syariah di Sidogiri. Dan pada pertengahan 1997 pengurus Kopontren dan beberapa guru MMU memprakarsai berdirinya koperasi serba usaha yang fokus usahanya adalah simpan pinjam pola syariah dengan nama Koperasi Baitul Mal wat Tanwil Maslahah Marsalal lil Ummah (BMT MMU).

Pendirian koperasi ini dilatarbelakangi karena resah dengan masyarakat sekitar yang mulai terjerat dengan praktik ekonomi ribawi dalam bentuk rentener yang sudah merambah sampai ke desa-desa sekitar Pesantren Sidogiri. Semakin hari koperasi mengalami perkembangan yang cukup bagus. Para pengelolanya adalah para santri dan para guru MMT. Meskipun para pengelolanyan khususnya guru-guru MMU yang biasanya berkutat dengan pelajaran kitab kuning merasa seakan-akan memasuki dunia lain ketika menangani bisnis syariah, namun mereka berhasil mengembangkan Koperasi BMT MMU.

Sikap kemandirian sebagai prinsip dasar Pesantren Sidogiri perlu didukung kekuatan finansial yang kuat. Koperasi Pesantren (Kopontren) Sidogiri, sejak kali pertama dirintis oleh KA. Sa'doellah Nawawie pada tahun $1961 \mathrm{M}$, dapat mengambil peran sebagai sumber penyokong keuangan utama di Pesantren Sidogiri. Dalam beberapa tahun terakhir, sekitar
$70 \%$ subsidi biaya operasional pendidikan di Pesantren Sidogiri disokong oleh SHU (Sisa Hasil Usaha) Kopontren. Dan berdasarkan laporan keuangan Per 31 Desember 2010, Koperasi BMT MMU Sidogiri telah memiliki aset sebesar Rp. 89.138.192.945,88. Manfaat riil Kopontren Sidogiri juga dapat dirasakan oleh alumni dan masyarakat umum. Keberadaan cabang Kopontren di sebuah daerah misalnya, secara tidak langsung turut meningkatkan perekonomian di daerah tersebut.

Selain itu, Kopontren Sidogiri menjadi salah satu sarana bagi santri untuk mengamalkan figh muamalah. Melalui Kopontren, konsep ekonomi syariah dalam kitab-kitab fiqh dapat diimplementasikan secara nyata di tengah masyarakat. Saat ini, Kopontren memiliki 36 cabang yang tersebar di Jawa Timur. Jenis usaha yang dikembangkan pun beragam, dengan empat klasifikasi utama: ritel dan grosir, layanan jasa, penyerapan produk Usaha Kecil dan Menengah (UKM), serta industri dan manufaktur. Kopontren Sidogiri resmi berbadan hukum sejak tanggal 15 Juli 1997. Semenjak itu, Kopontren Sidogiri dikelola oleh tenaga-tenaga ahli, dengan manajemen yang profesional. Keberhasilan pengelolaan kopontren ini dilandasi dengan penerapan prinsip manajemen rasul yaitu siddiq (jujur), amanah (dapat dipercaya), tabligh (transparansi) dan fathonah (profesional). Menurut KH. Mahmud Ali Zain, untuk bisa menunjukkan keprofesionalannya karena para pengelola banyak dari alumni pesantren yang hanya memiliki semangat siddiq dan amanah, maka profesionalismenya dilakukan dengan perpaduan praktisi dan akademisi. Profesionalisme dibina oleh akademisi, praktisi melakukan apa yang dibina sekaligus mengetahui lapangannya. Motto Kopontren Sidogiri yang dicetuskan oleh KH. Sa'doellah Nawawie adalah "Dari santri, oleh santri dan untuk santri".

Untuk meningkatkan keprofesionalan pengurus Kopontren, Kopontren mengadakan pelatihan marketing untuk seluruh 
administrator cabang. Narasumber yang diundang adalah bapak Aditia, Marketing Bank Central Asia (BCA). Kemudian bekerjasama dengan Asosiasi Koperasi Ritel Indonesia, Kopontren mengadakan pelatihan manajemen ritel untuk seluruh administrator cabang. Pemateri dari Efrata Consulting. Beberapa mitra kerja Kopontren Sidogiri antara lain dengan lebih dari 800 jaringan pemasok besar (PT Unilever, PT Wings, PT. HM Sampoerna, PT Indogrosir, Penerbit KALISTA), lebih dari 100 jaringan UKM dan Pengrajin, Koperasi (BMT-MMU dan UGT, Kop Nur ramadhani), Perbankan, LSM dan Investor Perorangan.

Selain terus menambah cabang baru di luar pasuruan, Kopontren Sidogiri juga bergerak cepat dibidang produksi. Sejak lama, produksi Air Minum Dalam Kemasan (AMDK) dengan merk "Santri" dan "Giriway" menjadi prioritas Kopontren. Pabrik AMDK yang semula berada di Desa Pakoren Rembang Pasuruan, sejak 11 Safar $1431 \mathrm{H}$ kemudian telah berpindah ke desa Umbulan Winongan Pasuruan. Kepindahan ini terkait keinginan pihak Kopontren untuk meningkatkan kapasitas produksi. Daerah Umbulan terkenal dengan sumber air alaminya yang bersih dan segar, dengan kualitas nomor satu. Seperti dikutip di $R a-$ dar Bromo, kualitas air kategori satu semacam di Umbulan hanya ada dua di dunia. Satu di Umbulan dan satu lagi di Paris Perancis. (Radar Bromo, 27/1/2010). Usaha AMDK diupayakan terus berkembang dan memiliki banyak cabang di berbagai kota di Pulau Jawa dan Madura. Bahkan ke depan, pabrik AMDK milik Kopontren juga berencana akan memproduksi air minum rasa.

\section{Perubahan Sistem Pendidikan dan Tokoh Perubahan}

Pada periode awal berdirinya pesantren di Indonesia sebagian besar menggunakan sistem salafiyah (sistem tradisonal dengan metode sorogan dan wetonan). Seiring dengan adanya era modernitas dan mempertahankan keberadaan pesantren ada beberapa pesantren yang mengadopsi sistem madrasah atau sekolah.

Namun untuk Pesantren Sidogiri tetap eksis dengan sistem salafiyahnya melalui sistem sorogan dan bandongan/wetonan (sistem ma'hadiyah). Kemudian melakukan pengembangan sistem madrasiyah berupa pendidikan nonformal (klasikal) yakni mendirikan Madrasah Miftahul Ulum yang dimulai dari jenjang Ibtidaiyah, berinovasi menjadi jenjang Tsanawiyah, dan terus berinovasi menjadi lengkap sampai jenjang Aliyah, yang dirancang dengan kurikulum salafiyah plus. Dan bahkan dalam perkembangannya Madrasah Miftahul Ulum yang semula star pada jalur nonformal, karena secara terus menerus berinovasi dengan menambah kurikulum di bidang ilmu pengetahuan umum, seperti Administrasi pendidikan, Psikologi Pendidikan, Didaktik Metodik, Ilmu Kesehatan, Psikologi Anak Usia Sekolah, Bahasa Indonesia, Pengantar Sosiologi, Sosiologi, Pengantar Psikologi, Matematika, dan sebagainya. Sehingga setelah melihat fakta proses pembelajaran pada semua jenjang dan tingkat pendidikan pada Pesantren Sidogiri, yang menggunakan kurikulum salafiyah plus Kementerian Agama memberikan apresiasi dengan melaksanakan akreditasi.

Oleh karenanya sejak tahun 2006 Ijazah Madrasah Miftahul Ulum secara formal telah diakreditasi oleh Departemen Agama (baca: Kementerian Agama), walaupun pada jenjang Aliyah. Jurusan yang digunakan bukan model jurusan madrasah aliyah pada umumnya (Agama, IPA dan IPS), tapi menggunakan jurusan Tarbiyah, Dakwah dan Muammalah. Lulusannya dapat diterima di Universitas Al-Ahgaf Hadramaut Yaman, dan bahkan pada tahun ajaran 2008-2009 Ijazah Aliyah memperoleh pengakuan/penyetaraan (mua'dalah) dari Universitas Al-Azhar Kairo, Mesir. Artinya lulusan Aliyah Sidogiri dengan ijazahnya dapat melanjutkan disana. Inovasi berikutnya, di sebagian Pesantren biasanya tidak berhenti untuk melayani pendidikan santri 
dengan bentuk pendidikan yang ada, yaitu MTs, MA, bahkan terus berusaha untuk mendirikan pendidikan tingkat tinggi baik formal dalam bentuk universitas atau maupun non formal dengan mendirikan $M a$ 'had Aly. Tapi kondisi ini berbeda dengan Pesantren Sidogiri, karena pada Pesantren ini belum memprogramkan untuk mengembangkan sampai ke jenjang pendidikan tinggi. Namun bagi santri Aliyah dan para Ustadz/Guru, terdapat program kuliah syariah yang dilaksanakan setelah 'isya, dan mendapat binaan langsung dan pengasuh. Kuliah Syari'ah ini banyak membentuk forum kajian Ilmiah, melaksankan pelatihanpelatihan membuat buku, dan menerbitkan majalah. Forum binaan Kuliah Syari'ah seperti LMF (Lajnah Murajaah Fiqhiyah), EFKIT (Forum Kajian Tafsir), EFKA (Forum Kajian Al-hadits), Efkisa (Forum Kajian Sastra Arab), LPSI (Lembaga Peneliti dan Studi), melakukan diskusi di perpustakaan Sidogiri, Dan lembaga ini menurut peneliti kedepan bisa dijadikan embrio pendidikan tinggi sebagai kelanjutan dari Madrasah Miftahul Ulum pada jenjang Aliyah, sehingga menjadi Ma 'had Aly Kuliatus Syar'iyyi.

Perubahan yang terjadi pada Pesantren Sidogiri dapat terlihat pada tabel di bawah ini:

Tabel 1: Perubahan sistem pendidikan

\begin{tabular}{|l|l|l|c|}
\hline No & \multicolumn{1}{|c|}{ Perubahan } & \multicolumn{1}{|c|}{ Tokoh } & Priodesasi \\
\hline 1 & $\begin{array}{l}\text { Tahun 1745 M pesantren di didi- } \\
\text { rikan. (Salafiyah dengan metode } \\
\text { sorogan dan wetonan) }\end{array}$ & Sayyid Sulaiman & 1745-1938 \\
\hline 2 & $\begin{array}{l}\text { Tahun 1938 M mendirikan MMU } \\
\text { Ml dan Is'tidadiyah (Non Formal } \\
\text { Klasikal). Terakreditasi Kemenag } \\
\text { tahun 2006 (formal) }\end{array}$ & $\begin{array}{l}\text { KH Abd. DJalil } \\
\text { bin Fadlil }\end{array}$ & 1938-1957 \\
\hline 3 & $\begin{array}{l}\text { Tahun 1957 mendirikan MMU MTs } \\
\text { (Non Formal klasikal). Terakreditasi } \\
\text { Kemenag tahun 2006 (Formal) }\end{array}$ & $\begin{array}{l}\text { KH Moh. Cholil } \\
\text { Nawawie Yahya }\end{array}$ & 1957-1982 \\
\hline 4 & $\begin{array}{l}\text { Tahun 1982 M mendirikan MMU } \\
\text { Aliyah. (Formal). Tahun 2005 mem- } \\
\text { buka jurusan Tarbiyah, Dakwah } \\
\text { dan Muammalah. Terakreditasi } \\
\text { Kemenag tahun 2006. Tahun 2009 } \\
\text { lulusan di terima di Univ Al Azhar } \\
\text { Kairo Mesir. }\end{array}$ & $\begin{array}{l}\text { KH Sirodjul } \\
\text { Millah Wahdin } \\
\text { dan KH Abdul } \\
\text { Halim }\end{array}$ & 1982-2010 \\
\hline
\end{tabular}

Tabel di atas dapat dijelaskan sebagai berikut: sejak berdiri tahun 1745 sampai dengan 1938 menggunakan sistem tradisional dengan metode sorogan dan wetonan/ban- dongan. Sistem pendidikan pada Pesantren ini menganut sistem pendidikan Pesantren salafiyah yaitu dikelola menurut dua sistem pendidikan Pesantren salafiyah (sistem ma'hadiyah sorogan dan wetonan) dan sistem klasikal (sistem madrasiyah dalam bentuk madrasah formal).

Pesantren ini mengalami perkembangan dengan sistem pendidikan nonformal dalam bentuk sistem pendidikan Madrasah yaitu mendirikan MMU Ibtidaiyah. Saat ini mempunyai ranting sampai 126 unit ranting Madrasah Miftahul Ulum di Kabupaten Pasuruan dan ada yang di luar Kabupaten Pasuruan. Untuk MMU Tsanawiyah, para lulusannya harus bertugas sebagai guru tugas di luar wilayah kabupaten dari kelahirannya selama satu tahun, bila lulus dalam melaksanakan tugas baru diberikan ijazah.

Tokoh perubahan bentuk sistem pendidikan pada Pesantren Sidogiri ini dapat dijelaskan sebagai berikut. Tokoh perubahan merupakan tokoh sentral di lingkungan Pesantren yang bersangkutan serta memiliki ilmu pengetahuan agama yang tinggi (Ulama), dapat dipertanggungjawabkan dibidang ilmu pengetahuan secara intelektual dan memiliki himmah yang kuat dalam memajukan pendidikan di pondok pesantrennya. Tokoh perubahan merupakan tokoh sentral yang berpredikat sebagai pendiri, pengasuh, atau ketua pengurus.

Terhadap tokoh-tokoh yang melakukan perubahan atau inovasi dalam sistem pendidikan di Pesantren Sidogiri adalah K.H.Abd. Djalil bin Fadli sebagai pendiri Madrasah Miftahul Ulum (MMU) di Pesantren Sidogiri Pasuruan pada 14 safar $1357 \mathrm{H}$ atau 15 April 1938 M. Pendirian MMU ini layak untuk dianalisis, mengingat perkembangan MMU ini sangat membanggakan di kalangan umat Islam khususnya masyarakat pesantren. Karena satu-satunya pesantren yang masih kuat dalam mengelola satuan pendidikan dengan sistem salafiyah, namun telah mendapatkan kemajuan yang 
pesat. Sebagai bukti MMU yang semula hanya merupakan satuan pendidikan jalur nonformal, dengan berinovasi secara terus menerus, dapat menjadi satuan pendidikan jalur formal dengan akreditasi Kementerian Agama. Sebagai konsekuensi logis dari hasil proses akreditasi itu, lulusannya dapat melanjutkan ke jenjang perguruan tinggi baik negeri maupun swasta. Oleh karenanya beberapa tahun yang lalu UIN Malik Ibrahim Malang sudah menjalin kerjasama tersebut, dalam bentuk bahwa lulusan Aliyah Sidogiri dapat diterima di UIN Malang. Lebih-lebih pengakuan dari dunia Intemasional seperti halnya Universitas AIAhgaff memberikan tawaran beasiswa bagi lulusan Aliyah Pesantren Sidogiri terbaik untuk melanjutkan studi ke Al-Ahgaff di Hadramaut Yaman. Dan bahkan terhitung tahun ajaran 1428- $1429 \mathrm{H}$ ini, lulusan Aliyah MMU dapat diterima di Universitas Al-Azhar Kairo Mesir. Perkembangan yang signifikan seperti ini sangat membanggakan umat Islam, dan ini berkat kerja keras sang kreator didalam meletakkan fondasi satuan pendidikan yang didirikannya.

Periodesasi terjadinya perubahan sistem pendidikan pada PP Sidogiri ini dapat dijelaskan sebagai berikut: kepada perubahan periode yang kedua membutuhkan waktu sekitar 19 tahun yaitu dengan mendirikan jenjang Tsanawiyah atau setingkat SMP. Pada saat terjadi inovasi yang ketiga ini Pesantren Sidogiri membutuhkan interpal waktu sekitar 25 tahun, yaitu pada tahun 1982 saat berdirinya MMU tingkat Aliyah yaitu 7 tahun.

Untuk mengadopsi keinginan pengasuh bahwa semua santri pendaftar baru harus bisa ditampung pada pendidikan Sidogiri, Pesantren mendirikan Isti'dadiyah sebagai tingkat persiapan memasuki pendidikan yang sesungguhnya pada jenjang berdasarkan kemampuan santri baru. Setelah tahun 1989 ini satuan pendidikan pada Pesantren Sidogiri terus berbenah dan berinovasi. Interval waktu sekitar 1,5 tahun itu tidak sia-sia untuk berinovasi. Bahkan setelah interval waktu empat tahun kemudian yaitu pada tahun 2009 secara resmi telah mendapatkan pengakuan (Mu'adallah) lulusan Aliyah MMU Sidogiri diterima di Universitas Al-Azhar Kairo Mesir.

Tujuan dari perubahan sistem pendidikan pada Pesantren Sidogiri ini dapat dijelaskan sebagai berikut: pertama, pada awalnya tujuan pendidikan Pesantren dengan dasar lillah billah serta bermodal niat ikhlas dakwah untuk menegakkan kalimatNya (Izzul Islam wal Muslimin), kedua, berkembang untuk menanamkan ethos tafaqquh fiddien di kalangan santri, agar mereka mampu memahami ajaran-ajaran Islam

Periodisasi yang dibutuhkan Pesantren Sidogiri sejak mulai berdiri pada tahun 1745 sampai adanya perubahan yang pertama pada tahun 1938, terjadi interpal waktu kurang lebih 193 tahun, yaitu berdirinya Madrasah Miftahul Ulum MMU) pada jalur pendidikan nonformal jenjang pendidikan dasar yaitu Ibtidaiyah atau setingkat Sekolah Dasar (SD). Kemudian menuju inovasi secara baik dan benar, berakhlak mulia, yang berimplikasi terhadap keluarga dan masyarakatnya, serta bangsa dan negara, berusaha mencetak santri sebagai kader dakwah merupakan implementasi dari tujuan menegakkan berlakunya syari 'at Islam yang berhaluan kepada dan melestarikan madzhab ahlus sunnah waljamaah. dan ketiga, sistem pendidikan Pesantren 
Temuan Penelitian ini dapat digambarkan sebagai berikut:

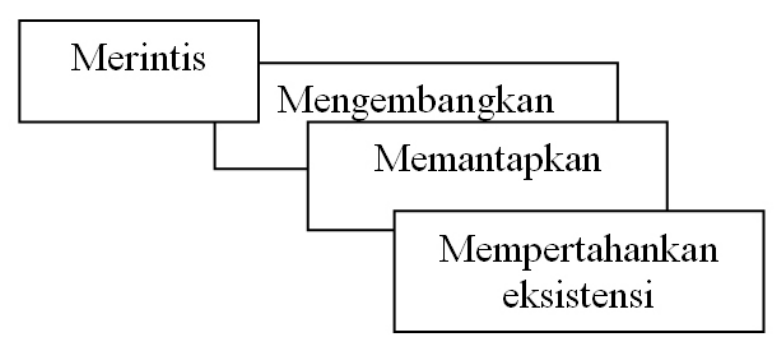

Bagi Pesantren Sidogiri, pada awal pendiriannya tujuan sistem pendidikan Pesantren dengan dasar lillah billah serta bermodal niat ikhlas dakwah untuk menegakkan kalimat-Nya (Izzul Islam wal Muslimin). Berkembang untuk menanamkan ethos tafaqquh fiddin di kalangan santri, agar mereka mampu memahami ajaran-ajaran Islam secara baik dan benar, berakhlak mulia, yang berimplikasi terhadap keluarga dan masyarakatnya, serta bangsa dan negara. Secara khusus tujuan Pesantren ini adalah membentuk sumberdaya manusia yang memiliki karakter "ibadikashalihin" yang patuh, tho'at kepada Allah swt dan berpegang teguh pada sunnah Rasulullah, serta memiliki pendirian yang bertanggung jawab, baik kepada diri sendiri, keluarga, masyarakat, agama, nusa dan bangsa .

Dalam realitas historisnya pendidikan Pesantren tumbuh dan berkembang dari, oleh dan untuk masyarakat Islam itu sendiri, sehingga sebenarnya sudah jauh lebih dahulu menerapkan konsep pendidikan berbasis masyarakat (community based education). Baik secara individu maupun organisasi (yayasan), membangun pendidikan Pesantren untuk memenuhi kebutuhan rnereka. Dan dalam perkembangan selanjutnya, Pesantren selaras dengan perkembangan masyarakat dan zamannya, maka dengan kesadaran sendiri mereka juga mau tidak mau haruslah mengikuti perkembangan masyarakatnya, yaitu dengan mengadakan perubahan sistem pendidikannya dari sistem tradisional sorogan dan wetonan kepada sistem klasikal model ma- drasah atau masih tetap mempertahankan sistem tradisional sorogan dan wetonan, tetapi menambah dengan sistem yang baru.

Sikap perubahan, inovasi dari sistem tradisional kepada sistem madrasah ini tentunya dilatarbelakangi oleh beberapa hal diantaranya adalah, (1) adanya pandangan yang mengatakan bahwa sistem pendidikan Islam tradisional (pondok pesantren) dirasakan kurang bisa memenuhi kebutuhan pragmatis masyarakat; (2) adanya kekhawatiran atas cepatnya perkembangan persekolahan umum yang akan menimbulkan pemikiran sekuler di masyarakat, (3) untuk menyeimbangknn perkembangan sekulerisme, maka masyarakat muslim, terutama pendidikan pondok pesantren dan para reformis, berusaha melakukan reformasi melalui penyelenggaraan dan pengembangan pendidikan berupa madrasah, sekaligus pemberdayaan madrasah yang sudah ada. (4) didorong semangat keagamaan dan da'wah Izzul Islam wal muslimin. (5) semakin langkanya generasi muslim yang mampu menguasasi ajaran Islam, baik secara kuantitatif maupun kualitatif, apaIagi sampai menguasasi totalitas ilmu agama Islam (aqidah, syari'ah dan akhlak), ini menunjukkan kemunduran kualitas ajaran Islam, yang berimplikasi terhadap kedangkalan pemahamam Islam dan munculnya persepsi eksklusif dan sebagainya.

Terjadinya perubahan ini (dari sistem tradisional kepada sistem klasikal/madrasah) adalah didorong oleh motif-motif yaitu: (1) sebagai manifestasi dan realisasi cita-cita pembaharuan dalam sistem pendidikan Islam, (2) merupakan salah satu usaha penyempumaan sistem pendidikan pesantren, agar mempertinggi kadar kualitasnya, dan (3) adanya sikap sementara masyarakat Islam yang lebih condong mengikuti sistem pendidikan persekolahan (umum) yang lebih memungkinkan anakanak mereka maju dalam ilmu pengetahuan dan teknologi, dan berijazah sebagai identitas intelektual. 
Pada Pesantren Sidogiri ini, dalam pengembangannya KH.Abd.Djalil Bin Fadhil (yang diikuti oleh penerusnya) selalu mengedepankan pembaharuan sistem pendidikan pondok pesantren, akan tetapi pada titik tertentu beliau masih tetap teguh mempertahamkan tradisi pendidikan salafiyah sebagai bentuk konsistensi (keistiqomahan) dalam pendidikan. Karena suatu alasan: (1) pelestarian warisan para ulama' salaf, (2) kesederhanaan sistem tersebut sehingga cukup mudah digunakan (aplicabel) dan biaya murah, dan (3) Sebagai media benteng terakhir jangan sampai ilmu-ilmu Keislaman punah. Namun demikian tetap memilki standar keseimbangan antara penerapan sistem baru (khalafiyah) dan pelestarian sistem salafiyah, dengan kaidah" $A l$ Muhaafadhotu alal qadimi ash sholih wal akhdu bil jadidil ashlah".

Oleh karenanya, tidak membuka pintu lebar-lebar untuk semua hal yang baru, tetapi dilihat terlebih dulu apakah hal itu banyak manfaat atau lebih hanyak mudharatnya. Apabila lebih bayak manfaatnya, maka pilihannya akan mengambil yang baru. Namun bila sebaliknya, maka sudah pasti akan tetap mempertahankan yang lama. Oleh karenanya dalam kasus pendirian Madrasah Miftahul Ulum ini, diambil dengan catatan tetap mempertahankan kurikulum dari kitab-kitab salafiyah, dan melaksanakan hal yang baru (sistem klasikal) disertai dengan materi yang bermanfaat bagi kelangsungan hidup/bekal kehidupan, karena dipandang bermanfaat demi kemajuan serta peningkatan bobot kualitas produk pesantrennya.

Selanjutnya khusus pada Pesantren Sidogiri Pasuruan, tujuan perubahan sistem pendidikan mempunyai motivasi tersendiri ialah untuk lebih meningkatkan kualitas alumni dibidang penguasaan kitab di samping tujuan lainnya yaitu membina dan membimbing santri yang belum mampu mengikuti pengajian kepada Kiyai MMU berdiri dengan menggunakan kuri- kulum sederhana yang kemudian diadakan penyempurnaan demi penyempurnaan sehingga seiring dengan perkembangan zaman lama kelamaan menjadi lembaga madrasah yang lebih jelas silabus dan tujuan institusionalnya. Bukan hanya itu saja, bahkan sekarang ini manajemen dari institusi Madrasah Miftahul Ulum (MMU) telah maju pesat sebagaimana manajemen sistem sekolah formal yang berstandar terakriditasi A.

Dengan demikian, apabila para santri di samping diberikan pendidikan ma'had dengan sistem sorogan dan wetonan juga mengikuti pendidikan melalui sistem madrasah diniyah plus. Dikatakan plus karena masih ditambah beberapa kursus pengetahuan umum seperti Pedagogik, Psikolgi Perkembangan, Administrasi Pendidikan dan Bahasa Inggris, dan sebagainya, mulai tingkat Tsanawiyah. Dengan maksud dan tujuan agar kualitas keluaran (alumni) santri Pesantren Sidogiri benar-benar mencapai tujuan yang diinginkan, yaitu menjadikan pribadi muslim mandiri, berakhlak mulia, yang memiliki kompetensi dibidang imtak, dakwah Islamiyah. Sehingga bila lulusan Pesantren Sidogiri, Pasuruan seperti itu, sudah barang tentu membuat pandangan masyarakat terhadap Pesantren Sidogiri semakin baik, positif yang berimplikasi terhadap animo masyarakat akan bertambah besar untuk menempatkan pendidikan anak-anaknya di pesantren ini. Lebih-lebih dengan keberadaan sistem Guru Tugas yang dilaksanakan oleh tamatan Tsanawiyah Sidogiri di mana pada setiap tahun lebih dari 600 orang yang tersebar hampir di seluruh wilayah Indonesia.

Hal ini terjadi setelah lebih kurang 192 tahun dari berdirinya Pesantren Sidogiri Pasuruan, sistem pendidikannya berubah dengan menambah sistem Madrasah Miftahul Ulum yang dilakukan dengan manajemen yang baik. Namun masih tidak meninggalkan sistem sebelumnya yaitu sistem tradisional berupa sorogan dan wetonan. Baik 
wetonan yang diberikan secara langsung oleh Pengasuh ataupun oleh guru-gurunya pada masing-masing daerah.

Pesantren Sidogiri secara obyektif memiliki potensi kekuatan yang besar dan memiliki kemampuan baik: (1) kemampuan untuk menciptakan suatu sikap hidup santri-santrinya ke arah mandiri, tidak menggantungkan diri kepada lembaga masyarakat yang manapun (ditunjukkan melalui kekuatan dibidang ekonomi), (2) kemampuan memelihara sub- kultur sendiri yakni kultur yang memiliki nilainilai budaya senidir/budaya santri, Pease Cultur (budaya damai), bias berarti nonviolence culture (budaya anti kekerasan), dan (3) Program terpadu yang memberikan peluang sangat besar kepada para santri untuk mengembangkan kemampuan dan bakatnya pada sekolah manapun yang ia kehendaki dan dipandang sesuai dengan potensi dirinya. Dengan model kehidupan Pesantren semacam itu telah membentuk masyarakat tersendiri, subkultur, yakni penciptaan suasana religius.

Di sisi lain, Pesantren Sidogiri memiliki beberapa pontesi yang menyebabkan pesantren Sidogiri tetap eksis walau menggunakan sistem pendidikan salafiyah, diantaranya:

Pertama, faktor institusional. Sistem pendidikan pada Pesantren ini memiliki manajemen modern dan dikelola dengan baik di semua institusi penunjang dengan terstandarisasi. Di pesantren Sidogiri bisa dilihat adanya kepemimpinan kolektif antara: Pengasuh/Pimpinan, Majelis Keluarga dan Pengurus yang menangani santri. Selain itu juga bisa dilihat adanya AD/ART pesantren, tata kerja pengurus-pengurus dan berbagai tata tertib. Seperti yang selalu dikatakan oleh KH. Mahmud Ali Zain bahwa budaya yang cukup dipegang teguh oleh para santri dan pengasuhnya adalah semua keputusan yang mendasar di dalam Pesantren berada di tangan pengasuh. Kemudian oleh para santri senior segala kre- ativitas dari sang kiai diimplementasikan bersama-sama dengan pengurus pondok.

Kedua, adanya potensi perekonomian yang kuat. Pesantren Sidogiri memiliki sumber pendanaan yang kuat sehingga melahirkan sikap mental yang mandiri (Self Reliance) dalam pengembangan sarana dan prasarana kependidikan. Pesantren mempunyai usaha perekonomian dibidang Kopentren dengan menggunakan manajemen modern. Kopontren memiliki 36 cabang yang tersebar di Jawa Timur dengan jenis usaha yang beragam: ritel dan grosir, layanan jasa, penyerapan produk Usaha Kecil dan Menengah (UKM), serta industri dan manufaktur.

Kopontren Pondok Sidogiri juga dikelola oleh tenaga-tenaga ahli, dengan manajemen yang profesional. Dilandasi dengan penerapan prinsip manajemen rasul yaitu siddiq (jujur), amanah (dapat dipercaya), tabligh (transparansi) dan fathonah (profesional). Untuk meningkatkan keprofesionalan pengurus kopontren, Kopontren mengadakan pelatihan Marketing dengan narasumber Bpk. Aditia, Marketing Bank Central Asia (BCA). Kemudian bekerjasama dengan Asosiasi Koperasi Ritel Indonesia, Kopontren mengadakan pelatihan manajemen ritel untuk seluruh administrator cabang.

Dengan kedua potensi tersebut pesantren Sidogiri terus berkembang dan maju, tetapi tidak ada perubahan besar yang mengubah kesalafan pesantren ini walaupun memiliki gedung yang megah, manajemen dan kepengurusannya telah begitu modern. Hal-hal prinsip yang mendasar dan tetap tidak akan berubah di pesantren yang telah memiliki ratusan madrasah filial di seantero Jawa Timur ini. Pengajaran kitab-kitab klasik tetap dijadikan sebagai inti pendidikan. Ajaran dan tradisi salaf tetap dijaga dan dipelihara dengan baik.

Itulah Pesantren Sidogiri, ajaran dan tradisinya salaf tapi manajemen dan fasilitasnya modern. Hal ini karena Sidogiri berpedoman dengan kaidah para kiai : " $A l-$ 
Muhafazhah 'alal-qadim ash-shalih wal-akhdu bil-jadid al-ashlah". Dan juga berpedoman kepada ucapan Sayyidna Ali bin Abi Thalib "Haqqun bighairi nizham yaghlibuhu bathilun bi nizham" yang artinya "kebenaran yang tidak tertata akan dikalahkan oleh kebathilan yang tertata".

\section{PENUTUP}

\section{Kesimpulan}

1. Perubahan bentuk satuan pendidikan yang dikelola oleh pesantren Sidogiri ini pada hakekatnya merupakan perubahan dari sistem pendidikan nonformal ke sistem pendidikan formal, dalam bentuk satuan pendidikan madrasah. Dengan kata lain perubahan-perubahan bentuk satuan pendidikan pada Pesantren sebagaimana disebutkan diatas, pada hakekatnya bukan perubahan sistem pendidikan pesantren, karena Pesantren Sidogiri tetap menjadi pesantren bertipologi salafiyah, namun masih tetap mempertahankan sistem pendidikan salafiyahnya, yaitu masih eksis dalam bentuk metode sorogan dan wetonan, bahkan ada usaha untuk lebih meningkatkan seperti kondisi awal berdirinya.

2. Tokoh perubahan (agent of change) dari setiap perubahan satuan pendidikan pada Pesantren ini adalah dari internal Pesantren khususnya pendiri, pengasuh, direktur, majelis keluarga, pada periodesasi kepemimpinannya dan di sisi lain kreator perubahan merupakan tokoh sentral yang memiliki kapasitas sebagai ulama intelektual atau intelektual ulama. Yang patut dijadikan sumber belajar sepanjang hayat, sangat progresif, mukhlis, (ikhlas lillahi Ta 'ala), dan tulus tanpa pamrih.

3. Periodesasiterjadinyaperubahansistem pendidikan ternyata tidak ada target interval waktu tertentu atau bervariasi sesuai dengan datangnya kebutuhan zaman, atau kebutuhan masyarakat, dan kesiapan sumber daya; organisasi pondok pesantren sendiri. Sedangkan interval tahapan periodesasi terjadinya perubahan bentuk satuan pendidikan Pesantren di samping tergantung dari tuntutan zaman, dan kebutuhan masyarakat, juga tergantung dari situasi dan kondisi internal, menurut pertimbangan sang kreator.

4. Pesantren Sidogiri yang selalu melakukan inovasi secara terus menerus mulai kondisi awal dengan sistem tradisional (salafiyah) berupa sorogan dan wetonan, kemudian ditambahkan perubahan menjadi sistem pendidikan nonformal (klasikal) dalam bentuk satuan pendidikan Madrasah Miftahul Ulum, dan tetap mendirikan kuliah syariah (tidak mendirikan perguruan tinggi/Ma'had Aly).

5. Kemandirian pesantren Sidogiri di bidang ekonomi yang ditandai pesatnya kemajuan yang dicapai oleh Kopontren Sidogiri dalam usaha ritel dan grosir, layanan jasa, penyerapan produk Usaha Kecil dan Menengah (UKM), serta industri dan manufaktur sangat memberikan manfaat baik para santri maupun para pengasuh dan pengurusnya yang mengakibatkan tidak adanya kebiasaan atau kultur meminta-minta (mengharapkan bantuan/sumbangan dari pihak lain) bahkan dapat menyantuni masyarakat dhuafa.

\section{Saran-Saran}

1. Bagi Direktorat Pendidikan Diniyah dan Pesantren agar dijadikan referensi untuk bahan kajian, bahwa Pesantren salafiyah Sidogiri ini, masih mempertahankan sistem pendidikan tradisional dan konvensional dengan membatasi diri pada pengajaran kitab-kitab klasik dan pembinaan moral keagamaan, di samping memadukan sistem pendidikan formal yang ada, dan ternyata 
model klasik/salafiyah yang terpadu ini memang unggul melahirkan santri yang memiliki kesalehan, kemandirian (dalam arti tidak terlalu tergantung kepada peluang kerja).

2. Bagi pelaku pendidikan khususnya pendidikan kepesantrenan, sudah menyadari benar tentang ketiga fungsi pendidikan pondok pesantren, yaitu (a) transmisi dan transfer ilmu-ilmu Islam, (b) memelihara tradisi Islam dan Ajaran Aswaja, (c) reproduksi ulama. Sedangkan sekarang yang masih kurang adalah mereproduksi ulama sebagaimana pada awal abad ke dua pulun (1920-1950-an). Oleh karenanya, perlu diupayakan secara istiqomah, agar dapat mencapainya kembali, yang salah satunya adalah untuk tetap melestarikan pesantren salafiyah. Oleh karena itu, Direktorat Pendidikan Diniyah dan Pesanten perlu mengupayakan pembinaan mutu dari pesantren-pesantren bertipologi salafiyah.

3. Upaya mempertahankan salafiyah dengan sistem management modern bahkan "go international" menjadi pilihan Pesanten Sidogiri untuk bisa dijadikan contoh pesantren-pesantren lain melakukan pilihan seperti Pesantren Sidogiri, yang berupaya untuk tidak ketinggalan zaman, namun target salafi tetap dapat tercapai atau terpenuhi. Direktorat Pendidikan Diniyah dan Pesantren dapat melakukan pembinaan pesantren di mana Pesanten Sidogiri dapat dijadikan sebagai percontohan.

\section{SUMBER BACAAN}

Abazza, Mona (1999): Pergeseran Orientasi Pendidikan Islam: Studi Kasus Alumni Al Azhar. Jakarta, LP3ES.

Abdullah, Taufik (1983): Agama dan Perubahan Sosial. Jakarta, Penerbit CV Rajawali.
Anasom (2007): Kyai, Kepemimpinan dan Patronase. Semarang, Pustaka Rizki Putra.

Azra, Azyumardi (2002): Pendidikan Islam, Tradisi dan Modernisasi Menuju Millenium Baru. Jakarta, Logos.

Abdul, A. Azis, dkk (2007): Islam Ahlussunnah wal Jama'ah di Indonesia: Sejarah, Pemikiran dan Dinamika Nahdlatul Ulama. Jakarta, Pustaka Ma'arif NU.

Assegaf, A.R (2003): Internasionalisasi Pendidikan. Yogyakarta, Gama Media.

Bafadhal, A.R (2006): Pergeseran Literatur Pesantren Salafiyah di Indonesia. Jakarta, Puslitbang Lektur Keagamaan Badan Litbang dan Diklat, Departemen Agama RI.

Bakhri, Moh. Syaiful (2011): Suskes Ekonomi Syariah di Pesantren. Jakarta, Cipta.

Bogdan, R.C. dan Bikle, S.K (1982): Qualitative Research for Education: An Introduction to Theory and Methods. Boston: Allyn and Bacon, Inc.

Bungin (2005): Analisis Data Penelitian Kualitatif Pemahaman Filosifis dan Metodologis ke Arah Penguasaan Model Aplikasi. Jakarta, PT Raja Grafindo Persada.

Dhofier, Zamakhsari (1994): Tradisi Pesantren: Studi tentang Pandangan Hidup Kyai. Jakarta, Penerbit LP3ES.

Donald K., Adams (1977): "Development Education ", dalam Comparative Education Review. Vol. 21, Nos 2 \& 3 June/ October.

Gazalba, S (1983): Islam dan Perubahan Sosial Budaya. Jakarta, Pustaka Alhusna.

Guba, EG and Clark L. David (1967): An Examination of Potential Chane Roles in Education, "in Rational Planning in Curriculum and Instruction, ed. Ole Sand. Washington DC, National Education Association.

Horikoshi (1987): Kyai dan Perubahan Sosial. Jakarta, LP3EM. 
Husen, Torsten (1979): The School in Question, A Comparative Study of the School and its Future in Western Society. Oxford, University Press.

Jejak langkah 9 Masyayikh sidogiri jilid 2, Pustaka Sidogiri, Tahun 1432 H

Joewono, Heri (2002): Pokok-pokok Pikiran Kepemimpinan Abad 21. Jakarta, Balai Pustaka.

Madjid, Nurcholish (1997): Bilik-bilik Pesantren: Sebuah Potret Perjalanan. Jakarta, Paramadina.

Mastuhu (1994): Dinamika Sistem Pendidikan Pesantren : Suatu Kajian tentang Unsur dan Nilai Sistem Pendidikan Pesantren. Jakarta, INIS.

Muhadjir, Noeng (1992): Metodologi Penelitian Kualitatif. Yogyakartam Rake Sara$\sin$.
Profil Guru GT dan Dai Sidogiri, 1431-1432 $\mathrm{H}$

Rahardjo, M. Dawam (ed.) (1985): Pergulatan Pesantren: Membangun dari Bawah. P3M, Jakarta.

Steenbrink, Karel A (1986): Pergeseran Madrasah Sekolah Pendidikan Islam dalam Kurun Modern. Jakarta, LP3ES.

TAMASSYA Taqriru Masulil Mahad Sanawiyan (Laporan tahunan Pengurus PP Sidogiri), 1430-1431 H, Membangun Budaya Hidup Bersih dan Sehat, jilid 8.

TAMASSYA : Taqriru Masulil Mahad Sanawiyan (Laporan tahunan Pengurus PP Sidogiri), 1431-1432 H, Pesantren Tempat Mendidik Hati jilid 9.

Wahid, Abdurrahman (2001): Menggerakkan Tradisi: Esei-esei Pesantren. Yogyakarta, LKiS. 